\title{
Hipnolaktasi Berpengaruh terhadap Onset Pengeluaran Kolostrum pada Ibu Nifas Primipara
}

\author{
Nur Masruroh $^{1}$, Ratna Ariesta Dwi Andriani ${ }^{2}$ \\ ${ }^{1,2}$ Program Studi D III Kebidanan Fakultas Keperawatan dan Kebidanan, Universitas Nahdlatul Ulama Surabaya \\ Email : ${ }^{1}$ masruroh@unusa.ac.id, ${ }^{2}$ ratnariesta@unusa.ac.id
}

\begin{abstract}
Abstrak
Kolostrum mulai diproduksi oleh tubuh saat kehamilan, dan keluar pada awal seorang ibu akan menyusui. Merupakan upaya untuk mempercepat pengeluaran kolostrum adalah menggunakan teknik hipnolaktasi. Teknik Hipnolaktasi adalah upaya alami menggunakan energi bawah sadar yang diberikan pada ibu nifas agar proses menyusui berjalan dengan aman dan lancar. Upaya ini dilakukan dengan cara memasukkan kalimat-kalimat afirmasi atau sugesti positif disaat ibu dalam keadaan sangat rileks atau sangat berkonsentrasi pada suatu tujuan sehingga Ibu dapat menghasilkan ASI yang mencukupi untuk kebutuhan tumbuh kembang bayi. Tujuan dari penelitian ini adalah untuk mengetahui pengaruh pemberian teknik hipnolaktasi terhadap onset pengeluaran kolostrum. Dilakukan penelitian di 2 BPM wilayah kota Surabaya dengan menggunakan metode Quasi Eksperiemen. Penelitian dilakukan dengan mengukur onset pengeluaran kolostrum pada kelompok perlakuan (20 responden) yang diberikan teknik hipnolaktasi kemudian dibandingkan dengan kelompok kontrol (20 responden) yang diobservasi onset pengeluaran kolostrumnya. Hasil penelitian menunjukkan $p=0,930(>0,05)$ yang artinya pemberian teknik hipnolaktasi tidak berpengaruh terhadap onset pengeluaran kolostrum. Rerata (mean) onset pengeluaran kolostrum adalah 13,2 jam pada kelompok perlakuan dan 15,7 jam pada kelompok kontrol. Hipnolaktasi mempercepat onset pengeluaran kolostrum pada ibu nifas primipara, tetapi tidak terbukti dengan penghitungan statistik.
\end{abstract}

Kata Kunci: Hipnolaktasi, Kolostrum,Onset, Primipara

\begin{abstract}
Colostrum begins to be produced by the body during pregnancy, and out at the beginning a mother will breastfeed. An attempt to accelerate the release of colostrum is using hypnolactation techniques. Hypnolactation technique is a natural effort to use subconscious energy given to postpartum mothers so that the breastfeeding process runs safely and smoothly. This effort is done by entering affirmations or positive suggestions when the mother is very relaxed or concentrates on a goal so that she can produce enough milk for the needs of the baby's growth and development. The purpose of this study was to determine the effect of the administration of hypnolactation techniques on colostrum ejection onset. The research was conducted in 2 BPM areas of Surabaya city using Quasi Experimental method. The study was conducted by measuring the onset of colostrum ejection in the treatment group (20 respondents) given the hypnolactation technique then compared with the control group (20 respondents) observed for the onset of colostrum ejection. The results showed that $p=0.930$ (> 0.05) which means that the administration of hypnolactation technique did not affect the ejection onset of colostrum. The mean (mean) onset of Colostrum uptake was 13.2 hours in the treatment group and 15.7 hours in the control group. Hypnolactation accelerates the onset of colostrum ejection in primiparous postpartum mothers, but it is not proven by statistical calculations.
\end{abstract}

Keywords: Colostrum,Hypnolactation, Onset, Primipara 


\section{Pendahuluan}

Menyusui adalah cara yang optimal dalam memberikan nutrisi dan mengasuh bayi, dan dengan penambahan makanan pelengkap pada paruh kedua tahun pertama, kebutuhan nutrisi, imunologi, dan psikososial dapat terpenuhi hingga tahun kedua dan tahun tahun berikutnya. ${ }^{1}$ Kolostrum merupakan cairan yang pertama kali disekresi oleh kelenjar payudara, mengandung tissue debris dan residual material yang terdapat dalam alveoli dan duktus dari kelenjar payudara sebelum dan setelah masa puerperium. Kolostrum merupakan cairan dengan viskositas kental, lengket dan berwarna kekuningan. Kolostrum mengandung tinggi protein, mineral, garam, vitamin A, nitrogen, sel darah putih dan antibodi yang tinggi daripada ASI matur. Selain itu, kolostrum masih mengandung rendah lemak dan laktosa. ${ }^{2}$ Kolostrum mengandung sel darah putih dan antibodi yang paling tinggi daripada ASI sebenarnya, khususnya kandungan immunoglobulin A (IgA) yang membantu melapisi usus bayi yang masih rentan dan mencegah kuman memasuki bayi. IgA ini juga membantu dalam mencegah bayi mengalami alergi makanan. ${ }^{3}$

Hasil penelitian Dewey, yang dikutip oleh Dina 2017 menyatakan bahwa 24\% dari ibu yang mengalami stres saat kehamilan dan persalinan, mengalami keterlambatan keluarnya kolostrum (>72 jam pasca persalinan). Faktor lain yang ikut berpengaruh terhadap lambatnya keluar kolostrum adalah: cara persalinan, lamanya persalinan, sakit yang dialami saat persalinan, dan keletihan setelah persalinan. Faktor lain yang juga mempengaruhi keluarnya kolostrum adalah status gizi ibu, perawatan payudara, isapan bayi segera setelah lahir serta obesitas pada ibu. $^{2}$

Upaya untuk mempercepat keluarnya kolostrum dapat dilakukan dengan cara farmakologi maupun non farmakologi. Pengeluaran kolostrum dapat dipercepat dengan menggunakan pemberian obat yang berfungsi melancarkan ASI. Sedangkan dengan non farmakologi dapat dilakukan dengan cara antara lain Inisiasi Menyusu Dini (IMD, Hipnolaktasi, relaksasi, masase, musik dan perawatan payudara. ${ }^{4}$ Hipnolaktasi dapat membantu ibu-ibu untuk memastikan agar ibu yang menyusui bisa terus memberikan ASI,minimal secara ekslusif selama enam bulan pertama, terutama apabila ibu menyusui tersebut harus kembali kerja.Dukungan untuk menyusui di Indonesia dirasakan masih kurang, oleh karena itu para ibu menyusui harus senantiasa berusaha menciptakan kondisi yang positif bagi dirinya untuk terus bisa menyusui. Hipnolaktasi merupakan teknik relaksasi untuk membantu kelancaran proses menyusui. Caranya memasukkan kalimat kalimat afirmasi yang positif yang membantu proses menyusui di saat ibu dalam keadaan rileks atau sangat berkonsentrasi pada suatu hal. Makna hypnosis sendiri adalah suatu kondisi nirsadar yang terjadi secara alami,dimana seseorang mampu menghayati pikiran dan sugesti tertentu untuk mencapai perubahan psikologis, fisik maupun spiritual yang diinginkan. Hypnosis sendiri terjadi otomatis kapanpun seseorang dalam keadaan rileks yang dalam atau berkonsentrasi penuh. Dalam teknik ini, perubahan yang diinginkan adalah segala hal yang mempermudah dan memperlancar proses menyusui. Contoh kalimat sugestinya: "ASI saya keluar lancar, cukup untuk kebutuhan bayi saya,", saya merasa bahagia bisa menyusui bayi saya", "saya bangga bisa memberikan yang terbaik untuk bayi saya", "saya selalu merasa tenang dan rileks di saat mulai memerah".

Hipnolaktasi terdiri dari dua kata yaitu hypno $=$ hipnosis yang artinya adalah suatu kondisi nirsadar yang terjadi secara alami, dimana seseorang menjadi mampu menghayati pikiran dan sugesti tertentu untuk mencapai perubahan psikologis, fisik maupun spritual yang diinginkan. Untuk diketahui, pikiran bawah sadar (subconscius mind) berperan $82 \%$ terhadap fungsi diri. Sedangkan breastfeeding artinya menyusui. Jadi, proses menyusui dapat berlangsung nyaman karena ibu merekam pikiran bawah sadar bahwa menyusui adalah proses alamiah dan nyaman. Dasar Hipnolaktasi adalah relaksasi yang dicapai bila jiwa raga berada dalam kondisi tenang. Adapun timbulnya suasana relaksasi dapat didukung oleh ruangan/suasana tenang, menggunakan musik untuk relaksasi, ditambah aroma therapi, panduan relaksasi otot, napas dan pikiran. ${ }^{5}$ 
Metode

Desain penelitian yang digunakan dalam penelitian ini adalah quasi eksperimen. Lokasi penelitian berada di 2 Bidan Praktik Mandiri yang berada di wilayah kota Surabaya. Populasi nya adalah seluruh ibu melahirkan di 2 Bidan Praktik Mandiri yang berada di wilayah kota Surabaya selama Februari 2017Januari 2018. Sampel dalam penelitian ini adalah sebagian ibu primipara yang melahirkan di 2 Bidan Praktik Mandiri yang berada di wilayah kota Surabaya selama bulan Mei-Juli 2018 sejumlah 60 responden yang diambil menggunakan teknik purposive sampling. Responden penelitian akan dibagi menjadi kelompok perlakuan yang akan diberi teknik hipnolaktasi 30 orang dan kelompok kontrol 30 orang. Variabel independen adalah Hipnolaktasi sedangkan yang menjadi variabel dependen adalah onset pengeluaran kolostrum. Kriteria inklusi nya adalah : ibu nifas primipara yang memasuki kala IV persalinan, sehat, bersedia menjadi responden dan mengisi inform consent. Kriteria eksklusi nya adalah : ibu nifas primipara yang memasuki kala IV persalinan dengan penyulit persalinan (perdarahan, infeksi, pre eklampsi dsb), tidak bersedia menjadi responden.

\section{Hasil \\ Karakteristik Responden}

Pada pengumpulan data didapatkan 60 responden, dengan pembagian masing masing 30 responden untuk kelompok perlakuan yang diberikan hipnolaktasi selama 30 menit dan 30 responden untuk kelompok kontrol yang diobservasi onset pengeluaran kolostrumnya. Keseluruhan responden adalah ibu yang baru melahirkan pertama kalinya (primipara Berdasarkan tabel 1 dibawah dapat dilihat bahwa $38 \%$ responden berada di rentang usia 20-35 tahun. Berdasarkan tabel 2 terlihat bahwa setengah responden berpendidikan terakhir di jenjang SMA.

Berdasarkan tabel 3 dapat dilihat bahwa rerata onset pengeluaran kolostrum pada kelompok perlakuan (yang diberikan hipnolaktasi) adalah 13,2 jam. Sedangkan pada kelompok kontrol reratanya adalah 15,7 jam. Berdasarkan tabel 4 Hasil uji statistik pada kelompok perlakuan dengan menggunakan Uji Independent $\mathrm{T}$ Tes diperoleh $\mathrm{p}$ value $(0,930)>$ 0,05 . Hal ini berarti tidak terdapat pengaruh hipnolaktasi terhadap onset pengeluaran kolostrum pada ibu nifas primipara. Hal tersebut menunjukkan bahwa terdapat faktor faktor lain yang dapat mempercepat onset pengeluaran kolostrum pada ibu nifas primipara.

Tabel 1. Karakteristik Responden Berdasarkan Usia pada Penelitian Pengaruh Hipnolaktasi terhadap Onset Pengeluaran Kolostrum Pada Ibu Nifas Primipara

\begin{tabular}{lcccccc}
\hline \multirow{2}{*}{ Usia } & \multicolumn{2}{c}{ Perlakuan } & \multicolumn{2}{c}{ Kontrol } & \multicolumn{2}{c}{ Total } \\
\cline { 2 - 7 } & $\mathrm{n}$ & $\%$ & $\mathrm{n}$ & $\%$ & $\mathrm{n}$ & $\%$ \\
\hline$<\mathbf{2 0}$ th & 10 & 33 & 9 & 30 & 19 & 32 \\
$\mathbf{2 0 - 3 5}$ th & 12 & 40 & 11 & 37 & 23 & 38 \\
$>\mathbf{3 5}$ th & 8 & 17 & 10 & 33 & 18 & 30 \\
\hline Jumlah & 30 & 100 & 30 & 100 & 60 & 100 \\
\hline
\end{tabular}

Sumber : data primer 2018

Tabel 2. Karakteristik responden berdasarkan tingkat pendidikan pada penelitian Pengaruh Hipnolaktasi terhadap Onset Pengeluaran Kolostrum pada Ibu Nifas Primipara

\begin{tabular}{llllcccc}
\hline Pendidikan & \multicolumn{3}{c}{ Perlakuan } & \multicolumn{3}{c}{ Kontrol } & \multicolumn{2}{c}{ Total } & \\
\cline { 2 - 8 } & $\mathrm{n}$ & $\%$ & $\mathrm{n}$ & $\%$ & $\mathrm{n}$ & 22 \\
\hline SMP & 5 & 16 & 8 & 26 & 13 & 50 \\
SMA & 15 & 50 & 15 & 50 & 30 & 28 \\
PT & 10 & 44 & 7 & 23 & 17 & 100
\end{tabular}

Sumber : data primer 2018 
Tabel 3. Onset pengeluaran kolostrum pada penelitian Pengaruh Hipnolaktasi Terhadap Onset Pengeluaran Kolostrum Pada Ibu Nifas Primipara

\begin{tabular}{lll}
\hline Statistik & \multicolumn{1}{c}{ Onset } \\
\cline { 2 - 3 } & Perlakuan & Kontrol \\
\hline Frekuensi & 30 & 30 \\
Mean & 13,2 & 15,7 \\
Median & 5,1500 & 5,0000 \\
Mode & 1,00 & 3,00 \\
Std Deviation & 2,1 & 1,9 \\
Minimum & 1,0 & 1,35 \\
Maksimum & 18,30 & 16,00 \\
\hline Suber
\end{tabular}

Sumber : data primer 2018

Tabel 4. Analisis penelitian Pengaruh Hipnolaktasi terhadap Onset Pengeluaran Kolostrum pada Ibu Nifas Primipara

\begin{tabular}{|c|c|c|c|c|c|c|}
\hline & & $\mathbf{N}$ & Mean & SD & $\mathbf{T}$ & Value \\
\hline Onset & Perlakuan & 30 & 13,2 & 2,1 & 0,88 & 0,930 \\
\hline $\begin{array}{l}\text { pengeluaran } \\
\text { kolostrum }\end{array}$ & Kontrol & 30 & 15,7 & 1,9 & 0,88 & \\
\hline
\end{tabular}

Sumber : data primer 2018

\section{Pembahasan}

\section{Karakteristik responden berdasarkan usia dan pendidikan terakhir}

Hasil penelitian menunjukkan bahwa distribusi frekuensi responden berdasarkan usia, dari 60 responden mayoritas (38\%) berada di rentang umur 20-35 tahun. Menurut Ruswana 2009, umur 20-35 tahun termasuk dalam usia reproduksi sehat bagi perempuan, dimana pada usia tersebut seorang wanita sudah siap secara fisik, emosi, psikologis, sosial dan ekonomi untuk hamil, melahirkan dan menyusui. Menurut Bahiyatun di tahun 2009, ibu ibu yang berumur kurang dari 35 tahun akan lebih banyak memproduksi ASI dibandingkan dengan ibu ibu yang usianya lebih tua.

Distribusi responden berdasarkan pendidikan terakhir, pada hasil penelitian dapat dilihat bahwa dari 60 responden, setengahnya $(50 \%)$ memiliki pendidikan terakhir di SMA. Notoatmodjo dikutip oleh Indah menyatakan bahwa tingkat pendidikan menengah atas akan lebih mudah dalam mengakses dan menerapkan suatu informasi yang diterima. Pendidikan dapat meningkatkan kemampuan seseorang pada ranah kognitif, afektif dan psikomotorik. Ranah kognitif mencakup pengetahuan, pemahaman, dapat menerapkan, melakukan analisis, sintesis, dan mengevaluasi. Hal ini akan mendukung perilaku menyusui. $^{2}$

\section{Pengaruh hipnolaktasi terhadap Onset pengeluaran kolostrum}

Onset pengekuaran kolostrum lebih cepat pada kelompok responden yang diberi hipnolaktasi $($ mean $=13,2 ; \mathrm{SD}=2,1)$ dibandingkan pada responden kelompok kontrol (mean $=15,7 ; \mathrm{SD}=1.9$ ). Hasil penghitungan analisis t-test independent didapatkan nilai $\mathrm{p}=0,930(>0,05)$ yang berarti $\mathrm{H} 0$ diterima dan H1 ditolak dengan demikian dapat disimpulkan bahwa tidak terdapat pengaruh pemberian hipnolaktasi dengan kecepatan onset pengeluaran kolostrum.

Berdasarkan hasil penelitian diatas diketahui bahwa pada responden kelompok perlakuan (diberi teknik hipnolaktasi) maupun pada responden kelompok kontrol tidak terdapat perbedaan onset pengeluaran kolostrum. Artinya tindakan pemberian teknik hipnolaktasi tidak berpengaruh terhadap kecepatan onset pengeluaran kolostrum pada ibu nifas primipara. Hal ini sesuai dengan hasil penelitian dari Lafaurie 2015 yang menyatakan bahwa salah satu manfaat dari hipnolaktasi adalah meningkatkan produksi dan aliran ASI, dan bukan mempercepat pengeluaran ASI. ${ }^{4}$ 
Onset pengeluaran kolostrum dipengaruhi oleh hal hal lain diantaranya adalah status gizi ibu, terlihat dari penelitian yang dilakukan oleh Wattimena di tahun 2015 menunjukkan bahwa 69\% ibu ibu yang memiliki status gizi baik atau IMT normal, onset pengeluaran kolostrumnya adalah $<12$ jam. ${ }^{6}$ Faktor lain yang mempengaruhi onset pengeluaran kolostrum adalah usia ibu pada saat melahirkan, menurut penelitian dari Indah 2015 dikatakan bahwa rentang usia terbaik yang memiliki onset pengeluaran kolostrum tercepat $\left(<12\right.$ jam) adalah di usia 20-30 tahun. ${ }^{2}$ Menurut hasil penelitian dari Hayatiningsih, diketahui bahwa ibu yang melakukan Inisiasi Menyusu Dini sebagian besar atau 77,5\% onset pengeluaran kolostrumnya lebih cepat $(<12$ jam). ${ }^{7}$ Sejalan dengan hal tersebut, penelitian dari Mawarti dan Mayasari di tahun 2014 menyatakan bahwa $64 \%$ ibu yang melakukan Inisiasi Menyusu Dini (IMD) onset laktasi nya berada pada kurun waktu $<12 \mathrm{jam}^{8}$

Pemberian teknik hipnolaktasi yang diawali sejak proses persalinan dengan metode hypnobirthing juga terbukti akan meningkatkan komitmen ibu dalam memberikan ASI ekslusif kepada bayinya. ${ }^{9}$ Ibu ibu yang melakukan teknik hipnolaktasi sendiri maupun dengan bantuan terapis menurut Pouget 2011, terbukti meningkatkan produksi ASInya. ${ }^{10}$ Sehingga pemberian teknik hipnolaktasi meskipun tidak terbukti berpengaruh terhadap onset pengeluaran kolostrum ibu, masih tetap baik dan diperlukan untuk mengoptimalkan proses menyusui.

\section{Kesimpulan}

Pada penelitian ini dapat disimpulkan beberapa hal, diantaranya adalah :

1. Rerata (mean) onset pengeluaran kolostrum pada kelompok yang mendapatkan perlakuan adalah 13,2 jam. Sedangkan pada kelompok kontrol adalah 15,7 jam

2. Onset pengeluaran kolostrum lebih cepat pada responden yang diberi hipnolaktasi, tetapi hasilnya tidak signifikan dalam uji statistik

\section{Saran}

1. Adanya penelitian lanjutan tentang pengaruh pemberian hipnolaktasi terhadap faktor faktor lain yang berhubungan dengan onset pengeluaran kolostrum
2. Peningkatan kompetensi tenaga kesehatan khususnya Bidan dalam memberikan konseling laktasi

\section{Ucapan Terima Kasih}

Penelitian ini didanai oleh DirJen Pendidikan Tinggi (RISTEKDIKTI) Kementrian Riset Teknologi dan Pendidikan Tinggi RI no 065/SP2H/LT/K7/KM/2018

\section{Daftar Pustaka}

1. Andriana E. Melahirkan tanpa rasa sakit dengan metode relaksasi hypnobirthing. Jakarta: BIP; 2007.

2. Indah $\mathrm{M}$.Faktor-faktor yang mempengaruhi waktu keluarnya kolustrum pertama kali pada ibu pasca persalinan di rsup dr. sardjito yogyakarta.(Internet).J Kebidanan Kendedes.2014(cited 12 Desember 2017 jam 12.00. available from http://jurnal.stikeskendedes.ac.id/index.php/m aternity/article/download/3/3

3. James T, Flores L SJ. Hypnosis: a comprehensive guide producing deeptrance phenomena. UK: Cromwel Press; 1-9 p; 2007.

4. Lafaurie E. Postpartum adaptation and competence of mothers who use hypnosis to birth. (Disertasi), Arizona State University,2015,(cited 20 Juni 2018 jam 08.00) available from https://repository.asu.edu/attachments/16405 2/content/Lafaurie_asu_0010E_15619.pdf

5. Armini N. Hipnolaktasi awali suksesnya asi eksklusif. (Internet).J Skala Husada.2015 Access 12 April 2017 jam 12.43. available from http://ejournal.poltekkesdenpasar.ac.id/index .php/JSH/article/download/10/32.

6. Wattimena I, Werdani YD, Manajemen laktasi dan kesejahteraan ibu menyusui, Jurnal Psikologi vol 42 no 3 Desember 2015:231-242.

7. Hayatiningsih N. Keluarnya kolostrum pada ibu post partum di rsud dr. moewardi.(thesis). Solo:Fakultas farmasi Universitas Negeri Solo.2016. Acces 10 April 2017 jam 21.08. available from https://publikasiilmiah.ums.ac.id/.../NURHAY ATININGSIH $\% 20 \% 20$ WINARSIH $\% 20$.

8. Mawarti R, Mayasari S. Inisiasi menyusu dini mempercepat onset laktasi, J Kebidanan dan Keperawatan 2014 Des vol 10 no 2;199-206.

9. Masruroh N, Laili U. Hipnolaktasi meningkatkan komitmen ibu dalam pemberian 
ASI eksklusif, Prosiding Seminar Hasil Penelitian Akbid YLPP ,2017, hal 101-105.

10. Pouget Lou, Self-hypnosis: How it can help with a better birth, Perspective - NCT's J On
Preparing Parents For Birth And Early Parenthood, Desember 2011:34-42 